\title{
Women's Bid for Equality in the United States in an Era of Backlash: Two Steps Forward and One Step Back
}

\author{
Katherine Stuart van Wormer* \\ University of Northern Iowa, Cedar Falls, IA, USA
}

\begin{abstract}
Women in the U.S. have made great strides in achieving equality and human rights as a result of activism and the political climate of the late 1960s. This paper will recall that progress but then show that a counter-reaction has set in, a reaction that is being paid for by mothers and disproportionately by women who are at the lower economic levels and among poor members of minority groups. This reaction is called backlash.
\end{abstract}

\section{THE FEMINIST PERSPECTIVE}

Feminism which sprang out of the women's movement offers a woman-centered approach to understanding behavior across the lifespan; this understanding extends from the treatment of infants and little girls to the challenges facing elderly women. The women's movement is often described in terms of three waves, the first of which took place during the struggle for women's suffrage. The First Wave ended with the passage of the $19^{\text {th }}$ amendment in 1920 which finally granted to women the right to vote. From the late 1960 s through the 1980s, The Second Wave was concerned with equality of opportunity, an end to blatant sex discrimination, and an acknowledgement of the physical victimization of women, whether on the streets, in the workplace, or in the home [1]. Members of the women's movement pressed for significant changes in labor law, reproductive laws, and social justice. An interesting fact about the women's movement is the extent to which it made (white, middle, and upper class) women aware of their own powerlessness apart from their connection to a powerful man which some had but many did not have, would never have. The new consciousness made women aware, moreover, for the first time of sexism in the language, for example, that the word man and the pronoun he were not universal after all but generally referred to just the male of the human race. In the early years of the movement (the late 1960s to 1970s) as women challenged the male power structure, the women's movement was ridiculed in the media and by the general public as a joke. It was referred to mockingly as "women's lib". But the biggest joke was on the opponents of the women's movement in an action designed to defeat the movement for civil rights legislation. This action had in fact happened several years earlier when a southern Senator who was a segregationist added sex to the 1964 civil rights act. This was his way of making a mockery of the act in order to ensure its defeat. Curiously, the fact that women actually could legally file claims of sex discrimination, as could other minority groups was largely overlooked until about a decade later.

During the same historical period as the mass people's rights movements and peace activism of the 1960s and

*Address correspondence to this author at the University of Northern Iowa, Cedar Falls, IA, USA; E-mail: katherine.vanwormer@uni.edu 1970s, feminist perspectives challenging the taken-forgranted patriarchal social structure filtered through the landscape. As defined by Van Den Bergh and Cooper [2], feminism is "a conceptual framework and mode of analysis that has analyzed the status of women (and other disempowered groups) cross-culturally and historically to explain dynamics and conditions undergirding disparities in socio-cultural status and power between majority and minority populations" ( $p$. xii). The central definition of feminism entails the conscious, explicit awareness that women are denied equal rights, opportunities, and access to goods and services [3]. Feminism is associated with social action in that it derives from political movements. However, it also represents a mode of analysis that has attracted extensive scholarship.

Feminist scholarship offers an enormous reservoir of information and links the political to the personal more effectively than any other theory. Feminist literature says a lot about gendered behavior and the tendency of some persons privileged by their gender to fight to maintain that privilege. These anti-oppressive theories also show how societies tend to maintain their institutionalized patterns of oppression through various means and how such patterns affect the behavior of the persons regarded as other, persons whose needs are not met. Feminist theorists are primarily concerned with issues pertaining to women although even here, different analyses exist with respect to the fundamental source of oppression in society [4]. Dominelli [5] and Payne [6] have filtered out from the feminist literature the following four types of feminism or feminisms:

- Liberal feminism seeks equality between men and women mainly through legislation and socializing children to enjoy more flexible roles.

- Radical feminism focuses concern on patriarchy, celebrates the differences between men and women, and promotes women's own separate structures.

- Socialist or Marxist feminism emphasizes women's oppression as part of structural inequality within a classbased social system. All oppressions are seen as interconnected and stemming from the same source. Power and violence in relations between men and women are not emphasized. 
- Black feminism starts with racism and draws parallels between racism and sexism. Black women's experience of oppression is heightened compared to that of white women.

To this list we can add ecofeminism. Ecofeminism is an environmental philosophy that starts with a view of the oppression of women and the oppression of nature as inextricably linked. The involvement of women in environmental policies bolstered this movement ensuring a focus on Mother Nature as well as on nurturance of human and non-human life. Ecofeminism asserts that the dichotomy between human beings and nature is a false one, and that famine and overpopulation are rooted in oppressive power structures [3].

Related contemporary developments in feminism are: the inclusion of the rights of women who choose to make their contribution in the home; a global consciousness of the repression of women in other cultures; a recognition of biological differences between the sexes that influences brain development; and a reinterpretation of feminism by the younger generation.

Third Wave Feminism consists of the daughters (and in some instances, sons) of feminists of the Second Wave. The cultural contribution of this development builds on the foundation of the Second Wave. A discernible negative view of their foremothers' militancy and consciousness-raising efforts is found among the younger generation of women. This rejection is characteristic of women who reject the movement altogether as well as of those women who understandably wish to carve out their own definition of feminism without giving up the fight for equal rights.

In Feminism Is for Everyone bell hooks [7] applies her critical analysis to misconceptions about earlier feminism, the beliefs by many people, first, that the movement was solely about gaining equality, and secondly, that feminism was anti-male. "Their misunderstanding of feminist politics," she states, "reflects the reality that most folks learn about feminism from the patriarchal mass media" (p. 1). She goes on to further explain, however, that there was indeed a great deal of anti-male sentiment among some early feminist activists who were responding to male dominance with anger: "It was that anger at injustice that was the impetus for creating a women's liberation movement" (p. 2).

Today, according the Seyler [8], American women are shying away from calling themselves feminists. She cites a Gallup opinion poll that showed that only one in four women were willing to call themselves feminists. This was a decline since the 1980s when a majority of women identified with the term feminist. Now, like then, however, the majority state that they support the women's movement and women's equality in the workplace.

A popular book written for Third Wave feminists is Manifesta by Baumgardner and Richards [9]. Written for young people, these writers differentiate the various waves of feminism without deriding any of them. They define the new feminism as an expanding feminism that is reclaiming the word girl but with a difference. Girlies, she tells us, are girls in their 20s and 30s who are into manicures, hair styles and the color pink. They are "reacting to anti-feminine, antijoy emphasis that they perceived as the legacy of Second
Wave seriousness" (p. 80). Baumgardner and Richards believe that young feminists should build on the legacy of the past rather than rebuild it. All feminisms, they suggest, share a struggle for justice and equality rather than paternalism and chauvinism. They see a common ground as young women pursue their course, "pushing voter registration, organizing against date rape, becoming women in rock, blowing the whistle in sexual harassment...and fighting for women's reproductive rights" (p. 79).

\section{U.S. MEDIA ATTACKS ON FEMINISM}

The mass media both reflect and shape the climate of opinion. Driven by market imperatives and unprecedented competition from multiple news sources, television and newspaper news editors are under pressure to produce feargenerated, sensationalized stories. The mass media, therefore, are playing a role, unwittingly or not in putting down the feminist movement. This statement is based on the fact that there is always the incentive in the mass media to come up with a new angle to an older story, to highlight a twist or paradox in the news. Popular literature generally echoes the new "insights" or "discoveries" and, in so doing, reinforces them. It is somewhat predictable, therefore, that the myth of the "new female criminal" has resurfaced in recent years to coincide with and justify woman's harsh treatment by the courts, civil (child custody) and criminal. The kind of misrepresentation of the facts of which I am speaking was evidenced in the publication of books such as When She Was Bad: How and Why Women Get Away with Murder [10] and articles such as one on female criminality that was published in Psychology Today: Tellingly entitled "Bad Girls" the article begins: "Violence by women has skyrocketed in the latter part of this century. Have they taken 'women's liberation' one step too far-or are they just showing their natural killer instinct?' [11, p. 54]. In fact, the claim is more political than factual. (See [12] and [13] as well as the Bureau of Justice Statistics for a review of the official statistics on women's crime from the late 1990s to the present time.)

The focus of the media hype, according to Chesney-Lind [14] has shifted from the girl gang member to the "violent girl" to the "mean girl". Today, for example, Odd Girl Out: The Hidden Culture of Aggression in Girls by Simmons [15] is a book that has attracted much interest. The "bad girls" focus has not gone away, however. It resurfaced again in the Newsweek article, "Girls Gone Bad?" by Deveny [16]. Such media hype, as Chesney-Lind suggests, has created a "selffulfilling prophecy" that has had dramatic effects on girls' arrests, detentions, and referrals to juvenile courts. Racial discrimination is certainly a factor here as African American females are disproportionately oppressed under harsh enforcement of the law.

The shift in direction away from male to female aggression that is evidenced in the media and criminal law and sentencing is paralleled in a turnabout in domestic violence research. Here there is a paradoxical, new focus on the victimization of males by female perpetrators. The following popular books, among others, proclaim this message: Cook [17], Abused Men: The Hidden Side of Domestic Violence; Buttell and Carney [18], Women Who Perpetrate Violence; James [19], Domestic Violence: The 12 
Things You Aren't Supposed to Know; Hise [20], The War Against Men; and Baskerville [21], Taken into Custody: The War Against Fatherhood, Marriage, and the Family.

In an appropriately critical article, entitled "Husband Abuse: Equality with a Vengeance," Canadian criminologists Minaker and Snider [22] draw on the facts to disprove the false claims that men and women are equally prone to violence. They demonstrate how the very successes of feminism, combined with neo-conservative governance, the burgeoning power of men's movements, and new communications media, have given rise to a frightening turnabout in national ideologies and practices. An antifeminist sentiment is apparent in the courtroom as well as in popular culture.

The War Against Boys: How Misguided Feminism is Harming Our Young Men [23], The Surrendered Wife [24], Women Who Make the World Worse and How Their Feminist Assault is Ruining Our Schools, Families, Military, and Sports [25] - these are among the publications that have gained media attention in recent years. Interestingly, the authors of such works define themselves as feminists. And yet.... their dismissive attitudes toward feminist issues-from sexual harassment to domestic violence to rape to pay equity to child care to welfare rights-are in effect an attack on women' equality and on the women who have fought for it.

\section{ECONOMIC PROGRESS OF WOMEN IN THE U.S.}

In the United States, the divorce rate is high, and there is a high rate of babies born to single mothers. Of families headed by single women, $37.1 \%$ are below the poverty line. (This is the line below which people cannot afford adequate food, housing, and so on). The term feminization of poverty applies to the disproportionate numbers of women compared to men who live below the poverty line. When the ratio of women's full-time income reached $81 \%$ of men's income in 2005, it was an all-time high, according to the U.S. Bureau of Labor Statistics [26]. The inequality for white women is that they earn $80 \%$ of what white men do; African American women do better at $89 \%$ of African American men's earnings, and Hispanics at a comparable $88 \%$. Although Asian Americans earn the most of all ethnic groups, Asian American women earn only $81 \%$ of what their men folk do. Before the women's movement, in the early 1960s, women earned only little more than $60 \%$ of what men did. This narrowing of the gender earnings gap, especially in recent years, does not reflect a rise in women's income as much as a decline in men's income in the trades and manufacturing from the 1980s to today.

The rising jobless rate is harder on women than on men in many ways. Women's unemployment reached $9 \%$ in 2003. It is significantly harder for women to maintain steady employment, given their low wage and part-time, often interrupted work [27]. Keep in mind that women are more likely than men to leave their jobs due to family illness, also there may be problems pertaining to sexual harassment or domestic violence.

The causes of female poverty are complex. The high divorce rate coupled with the infrequency of mothers receiving child support from the fathers forces many women to find jobs immediately or go on welfare. Low-paying service jobs - such as waiting tables in fast-food restaurants and motel housekeeping work-drive many women to welfare dependency as a means to escape from such daily drudgery, lack of essential work benefits, and childcare concerns. Programs designed to compensate for the absence of a male breadwinner in the family are means-tested and highly punitive. When men are absent, women's prescribed role as family caretaker is ignored and devalued by the system - a fact which reinforces women's marginality in society and ensures women and their children's high representation among the destitute. Until the importance of nurturing and shaping young lives through domestic caretaking is regarded as primary work, the feminization of poverty will continue. The federal and state program reductions in job training, education, and childcare implemented by the Reagan, Bush, Clinton, and George W. Bush administrations have had a major impact on already poor women and children.

In the best-selling book, Nickel and Dimed, Ehrenreich set out to see for herself what life at the margins of low-wage jobs is like [28]. She discovered that for women even without children affordable housing was hard to get. Her coworkers often lived in their cars or shared crowded apartments with relatives.

Women who are mothers of small children can qualify for welfare benefits for short periods of time only, and they must be involved in employment training to qualify for a job. This pressure to work has come about through laws that were passed in the Clinton administration, the 1996 Personal Responsibility and Work Opportunity Reconciliation Act. Collectively, this accumulation of cutbacks has served to legitimize the negative attitudes held by many Americans toward the poor. Also as long as working and middle class mothers with children are joining the labor market (to help ends meet), the sentiment is that other women should not have another option.

At the end of the life span, women pay again for their abbreviated, low-paid work careers. Qualifying far less frequently than men for adequate pension plans, most elderly women must rely on Social Security as their sole source of income. Accordingly, $14 \%$ of elderly females compared to $8.4 \%$ of elderly males are in poverty [29].

\section{BACKLASH AGAINST WOMEN IN U.S. SOCIETY}

Susan Faludi, [30] noted a cultural ethos that was decidedly anti-intellectual as well as anti-feminist which characterized the country from the 1990s. This development helped inspire the landmark publication of her Backlash: The Undeclared War against American Women. Backlash is a phenomenon borne out of success; one party makes claims, advances and another party feels left out, resentful and threatened. "This counterassault," writes Faludi (p. xviii), "stands the truth boldly on its head and proclaims that the very steps that have elevated women's position have actually led to their downfall." Liberation now, as Faludi further suggests, has became the true American scourge. Just when women's quest for equal rights had started to gain ground with extensive affirmative action programs in place; just when women had joined the ranks of virtually all the male dominated and prestigious and even macho professions; and when laws protecting rape victims and battered women from 
being belittled and attacked in court, almost predictably an antifeminist resistance set in. Two steps forward and one step back.

First, the two steps forward. Although women are still a long way from achieving full equality, the changes that have taken place-notably in the areas of control of reproduction, fairness in employment, and legal protection from harassment and other victimization - were resented by many men, especially those facing employment insecurity. Despite male resentment, the clock cannot be turned back on women's bid for equality in those countries where women have entered the power structure. Women continue to enter the professions such as law and medicine in record numbers and legislation tightened up to protect female victims of domestic assault while a new awareness of date rape and its connection with substance abuse has led to prevention measures such as on the college campus. Globally, women are beginning to organize to bring media attention to the needs of girls and women sold into sexual slavery and ravaged by genital mutilation.

The step back relates to the punishment of women, both biologically and legally. I am referring here, first, to the preoccupation with control of women's bodies under the guise of protecting the unborn child. The restriction in federal funding for abortions, as always, brought a disproportionate effect to bear on poor and minority women. Internationally, the American Right to Life movement as backed by the U.S. government has been successful in preventing ratification of human rights conventions because of the refusal of international bodies to protect the rights of children "born and unborn" as well as in jeopardizing the funding of family planning programs worldwide.

A related issue, because it also relates to the female body, and again reveals the interplay of race, class, and gender in the areas of pregnancy and motherhood, is the criminalization of high risk pregnancy. The prosecution of drug-addicted mothers is a part of an alarming trend toward greater state intervention into the lives of pregnant women under the guise of protecting the fetus from harm [31]. Still, this post-pregnancy prosecution does little to protect the child. Because of their closer contact with government agencies and their unlikelihood of having a private physician, poor black women bear the brunt of the prosecutors' punitive approach. These issues, moreover, are all of the "equality with a vengeance" or the "you can't have it both ways" variety of getting back at women. Thus in the name of equality, single mothers on welfare are forced to look for work. Ironically, the earlier welfare aid program (Aid to Families of Dependent Children) which was instituted to enable mothers to stay home with small children has now been turned on its head and replaced with mandatory welfare-to-work programs.

Faludi [32] goes further than other writers to explain the origins of the backlash. She does this remarkably well in Stiffed: The Betrayal of the American Man which indirectly refers to economic forces that have a bearing on men's social and work roles. In reading the personal narratives of very average and often sexist men, we get a sense of a lot of anger and of where their anger is coming from - from pressures from work, pressures that are related to forces in the global economy - downsizing, privatization, outsourcing, reduction in benefits. From the devastation of feeling they are losers in their breadwinning roles, men express a sense of emasculation and a longing for the security of the past. The visibility of women taking men's work roles has caused many men, as Faludi suggests, to feel oppressed by the image culture. Places of work that represented a particular vintage of masculinity such as the shipyard are no longer male bastions of pride. "If they were the losers, women had to be the winners" (p. 420), Faludi writes. Such putative accomplishments by women are bound to be resented. The blame these men place not on the workplace or politics or the economy but on another nationality, another race, and another sex. Sometimes they join right wing male bonding groups such as the Promise Keepers or Fathers' Rights groups. Sometimes they resort to violence, displacing their aggression onto weaker family members. Faludi cites James Gilligan, an expert on male violence, who contended that the emotion of shame is a primary factor all male violence. To the extent that this is true, one can detect a sense of shame in the personal narratives of the working class males who Faludi interviewed for her book-men who had been laid off from shipyards, mines, logging, and so on, men whose hopes of fulfilling the American dream have been jeopardized.

\section{BACKLASH AGAINST WOMEN IN THE U.S. CRIMINAL JUSTICE SYSTEM}

The treatment of female victims of male crime by the courts, we can view as a microcosm of the wider society. Women's experiences and participation here tell us a lot about the cultural norms as these pertain to gender expectations. Issues that the wider society is wrestling with should men and women be judged according to the same criteria (such as physical fitness standards) or should gender differences be taken into consideration - also come into play with regard to the law and its enforcement. This issue is as relevant for victims of rape and partner battering as it is for individuals in trouble with the law.

Welfare women, pregnant out-of-wedlock women, mothers with drug problems, female offenders, and even, to some extent, battered women (whose plausibility is being undermined): all are singled out for the new medicine. The message was loud and clear: the day of entitlements for many welfare services is over; women are now equal and most work (regardless of child care responsibilities) was echoed in the halls of justice where the message was, "You as the equal of a man will be punished like a man."

The execution of Karla Faye Tucker in 1998 in Texas, a young woman who was guilty of horrible crimes involving axe-murders but who turned her life around in prison is a case in point, a woman who paid with her life for the new equality standards as she had to bear the penalty of death like a man. As of 2007, ten other women have followed her to the execution chambers; there are 51 women on death row. Feminists do not raise their voices on behalf of such women because to do so would imply that women were weak and therefore unequal. The paradox is that women without education or opportunity to advance - those most likely to be arrested for criminal behavior - are held to the very standards of equality which have opened the doors professionally for another class of women altogether. Few female offenders are feminist and fewer still have benefited in any tangible way 
from the various affirmative action programs which have helped women advance up the ladder of the prestigious and academic professions.

As compassion takes a back seat in a punitive society, women connected to crime through family ties - mothers who protect their drug dealing children, wives and girlfriends of drug using men, for example - are now subjected to punishment under the "firm arm of the law." Chesney-Lind and Pollack [33] deemed this trend, "equality with a vengeance." More recently, Chesney-Lind [14] uses the term "vengeful equity" to refer to the gender blind treatment of women by the major institutions of society.

From the feminist criminology literature (for example, see $[14,22,33])$, we learn of the following examples of punitive policies. Especially relevant to poor and minority women in the U.S. are the following:

- The social construction of the "new female criminal," the typical variety of which is a drug-dependent mother who lives in the inner-city and got swooped up in an anti-drug operation;

- Conspiracy drug laws that are used to incarcerate large numbers of the female partners of drug dealers;

- The passage and enforcement of fetal abuse statutes which criminalize maternal drug use;

- Increase in the incarceration rates of drug using women that is significantly greater than the increase for men;

- New adoption laws that remove all custody rights from mothers in prison who are serving lengthy sentences;

- Use of dual arrest laws to arrest both partners in domestic violence situations;

- Laws that persons convicted of drug offenses cannot receive welfare aid.

While gender-neutral policies have dumped single mothers off the welfare rolls, gender-neutral mandatory sentencing for drug law violation has brought unprecedented numbers of women and especially black women into prison. Equality for these women subjects them to discipline according to the male model without allowance for their motherhood roles or their history of personal victimization. A flawed notion lurks beneath the current policies: the assumption that women have achieved full equality and that men are suffering the consequences. The backlash is felt most by the women least able to take advantage of the new professional opportunities and the least feminist identified. The media demonization of the "new violent female", especially young girls in trouble with the law, further aggravates the female offender's plight.

This vengeful equity phenomenon comes into play most concretely in the correctional arena. This fact is seen in connection with the masculinization of correctional services and standardization of treatment philosophies The bulk of the funding here has gone to high-tech security systems and to surveillance rather than to educational and counseling services. Consistent with the new mythology, the rate of construction of women's prisons now exceeds the male rate. And in accordance with the new thinking on female criminality, these structures are designed according to the male model of high-security fortresses; such facilities now are often male-run and male-administered with predictable results. The fact that the majority of women in confinement have been convicted of nonviolent, mostly drug-related offenses tends to be overlooked. For the female offender, chivalry is out; "equality" is in, and how can feminists argue for special treatment for women involved in crime while demanding equality for themselves? In any case, with public sentiment now turning against them, offenders with a history of personal victimization, chided for using the "abuse excuse" are apt to be further victimized by the legal process when charged with crime.

\section{THE IMPACT OF THE BACKLASH ON DOMESTIC VIOLENCE SERVICES}

Buttell and Carney [18], in their edited anthology, Women Who Perpetrate Relationship Violence, state as their purpose the desire "to strip away political correctness and take a frank look at the issues surrounding female violence in intimate relationship" (p. xvi). The first paper by Canadian social scientists Dutton, Nicholls, and Spidel [34] cites study after study from the social science literature to show that women initiate violence as much as men. Had the authors consulted the Bureau of Justice Statistics [35], they would have discovered that men kill women about three times as often as women kill men. Had they consulted the National Victimization Survey, these researchers would have learned that women make up $85 \%$ of all intimate assault victims [35]. The authors made the same mistake as the North American media in basing their conclusion that women are more violent than men from survey data gathered in the 1980s that relied on an instrument, the Conflict Tactics Scale. This survey asked the number of times they had slapped, kicked or otherwise hit a partner. This instrument is problematic because its exclusive focus is on acts performed rather than on the context in which the slapping, kicking, etc. occurred.

From an economic perspective, the impact of marketdriven measures of capitalism is causing the reduction of female-oriented social services through cut-backs, privatization of services, and the de-professionalization of workers. At the same time, global market forces pave the way for social service agency consolidation and corporate management techniques with the result that men displace women managers [36]. In the current backlash climate, the opportunity is being seized by right wing constituents to reduce funding for feminist-based social services. The loss of welfare benefits and services by the state, in conjunction with de-institutionalization of mental patients, in turn, has increased the numbers of homeless young people roaming the streets; this fact has intensified the vulnerability of girls and women to sexual victimization, sexual exploitation, and drug use. A parallel reduction in funding for victim assistance services and women's shelters has been pronounced.

\section{THE LEGACY OF THE IRAQ WAR}

Unique to the military is the training of men (and women) to kill. In warfare, combat conditions the soldier to kill almost as a reflex in a situation of danger. Military socialization "to make a man out of the boy" not only attempts to obliterate all that is feminine but also breeds 
misogynous heterosexuality in the soldier as well [37]. The degradation of traits such as weakness in battle, squeamishness, and compassion of traits associated with femininity, helps create or preserve masculine detachment and aggression desirable for battle. Such conditioning can be devastating for later family functioning.

On the home front, a condition such as post-traumatic stress disorder (PTSD), or a state of intoxication (even being suddenly aroused from sleep) can trigger violence. Depression related to PTSD can lead to suicide. Anderson [38] studied the seven homicides and three suicides that have taken place in western Washington State by returning soldiers from the war on Iraq. Five wives, one girlfriend, and a child have all been killed. Two of the suicides were committed after murder. These cases and others like them reported across the United State seem to suggest that as an anti-war slogan popular in the sixties said, "War is not good for people or other living things."

Female soldiers returning from the wars in Iraq and Afghanistan are often suffering from PTSD of a genderspecific sort - rape victimization, not at the hands of the enemy but by fellow soldiers. This fact was highlighted in a cover story in the New York Times Magazine by Corbett [39]. The rates of sexual harassment and assault are known to rise during wartime, as stated in the article.

\section{CONCLUSION}

There are two kinds of backlash we have discussed in this paper - institutionalized and personal. Institutionalized backlash operates at the societal level, typically as laws that are written or enacted as a reaction against progress by a minority group. Personal backlash may have its origins in social or work stress and is manifest as displaced aggression onto another person such as a family member. Sometimes this backlash takes the form of violence. Both forms of backlash, whether at the macro or micro level, are cultural in origin and derive from basic prejudice against girls and women, but especially against girls and women who are seen as competitive with men and therefore threatening. Resentment against the progress of affirmative action in western countries is matched by resistance to these democratic ideals in totalitarian nations. In the Western part of the world, new laws that move old protections have been introduced in combination with budget cuts of feministbased services, while in the Middle East, old laws restricting women's freedom have been reintroduced. Women's bid for equality has been used against girls and women in the United States, and poor and minority women in trouble with the law have paid for the male resentment against their more liberated sisters. Much of the backlash that we considered took the form of attempts to reverse feminist-inspired policies and activities.

Backlash, at its most basic level, is about power and control and fear of loss of that power and control. Backlash is also a response to anger and resentment by individual males whose place in society is undergoing rapid change, often faster than they can psychologically handle.

The current backlash mentality is pervasive worldwide. Today we are living in a globalized economy characterized by rapid change and strenuous competition among nations, corporations, and workers. The stress on families and communities is severe; men whose "sense of their own manhood flowed out of their utility in a society" as Faludi [32] (p. 607) terms it, are often seen to be "fighting a world transformed by the women's movement" (p. 413). Every social movement breeds a counter reaction, and as some individuals are losing their place in the world, even from forces that have nothing to do with the women's increasing equality, some men are lashing out at the most vulnerable people in their lives - women. Psychologists call this displaced aggression. In the western world, two decades of the corporate media's demonizing of girls and women has become, as Chesney-Lind [14] contends, a self-fulfilling prophecy as reflected in a masculinization of the treatment of women in the criminal justice system. Such attacks on girls and women are under the guise of equality. Another form of displaced aggression is seen in the privacy of the home in domestic violence. In some non-western nations, the form that the displaced aggression takes is a virtual war on women's self-expression and their rights.

Advocacy for gender specific rather than gender neutral treatment of women, in the courts as in correctional institutions and family life is a must. It is a must because equality laws and arguments are being used against girls and women, for example, in defining domestic violence situations as fights and in arresting both parties, in according men equality in child custody hearings, in overlooking battered woman defenses in drug cases in which the partner is prosecuted along with the offender.

In this era of political backlash, above all, feminist analysis is essential to criminological research, research to counter the myths of female violence being perpetrated in books and media hype based on the "revelations" about girls and women in such books. Feminist criminologists can help spread the word on what the research data show by writing letters to the editor and contacting reporters on a regular basis to clear up such fallacies that are being spread in the media. Awareness of conditions and strategies that lead to equality-with-a-vengeance traps is essential so that women's advocates can avoid falling into one of these traps. Activism through lobbying legislators on behalf of increased funding of domestic violence and victim assistance services is paramount as well. As educators, feminist social scientists would do well do adopt a global, human rights perspective on violence against women in the U.S. and worldwide and seek remedies provided through non-governmental organizations such as Human Rights Watch and Amnesty International. The U.S.'s failure to ratify many important human rights documents, however, undermines the ability of activists in this regard.

\section{REFERENCES}

[1] Owen AS, Steen S, Vande Berg L. (2007). Bad girls: Cultural politics and media representations of transgressive women. New York: Peter Lang 2007.

[2] Van Den Bergh N, Cooper LB. Introduction to feminist visions for social work. In: Tropman JE, Erlich JL, Rothman J, Eds, Tactics and techniques of community intervention, $3^{\text {rd }}$ ed. Itasca, IL: F.E. Peacock 1995; pp. 74-93.

[3] van Wormer K, Besthorn FH, Keefe T. Human behavior and the social environment, macro level: Groups, organizations, and communities. New York: Oxford University Press 2007. 
[4] Mullaly B. Challenging oppression: A critical social work approach. Don Mills, Ontario: Oxford University Press 2002.

[5] Dominelli L. Feminist social work theory and practice. New York: Palgrave 2002.

[6] Payne M. Modern social work theory, $3^{\text {rd }}$ ed. Chicago: Lyceum 2005.

[7] hooks b. Feminism is for everybody: Passionate politics. Cambridge, MA: South End Press 2000.

[8] Seyler M. Feminism: It's what women don't want. American Observer 2007, April 25. Retrieved 2007 August from: http://www.americanobserver.net/2007/04/25/feminist.

[9] Baumgardner J, Richards A. Manifesta: Young women, feminism, and the future. New York: Farrar, Straus \& Giroux 2000.

[10] Pearson P. When she was bad: How and why women get away with murder. New York: Penguin 1998.

[11] Yeoman B. Bad girls. Psychol Today 1999; 54-57: 71.

[12] Pollock JM. Counseling women in prison. Thousand Oaks, CA: Sage 1998.

[13] van Wormer K, Bartollas C. Women and the criminal justice system, $2^{\text {nd }}$ ed. Boston: Allyn \& Bacon 2007.

[14] Chesney-Lind M. Patriarchy, crime and justice: Feminist criminology in an era of backlash. Femin Criminol 2006; 1 (1): 626.

[15] Simmons R. Odd girl out: The hidden culture of aggression in girls. Darby, PA: Diane Publishing Co. 2005.

[16] Deveny K. Girls gone bad? Newsweek 2007, pp. 41-47.

[17] Cook PW. Abused men: The hidden side of domestic violence. Westport, CT: Praeger 1997.

[18] Buttell F, Carney M. Women who perpetrate relationship violence: Moving beyond political correctness. Binghamton, NY: Haworth Press 2005.

[19] James T. Domestic violence: The 12 things you aren't supposed to know. San Diego: Aventine Press 2003.

[20] Hise R. The war against men. Oakland, OR: Elderberry Press 2004.

[21] Baskerville S. Taken into custody: The war against fatherhood, marriage and the family. Nashville, TN: Cumberland House Publishing 2007.

[22] Minaker J, Snider L. Husband abuse: Equality with a vengeance. Can J Crim Crim Jus 2006; 48 (5): 753-780.

[23] Sommers CH. The war against boys: How misguided feminism is harming our young men. New York: Simon \& Schuster 2001.
[24] Doyle L. The surrendered wife. New York: Simon \& Schuster 2001.

[25] O'Beirne K. Women who make the world worse: And how their radical feminist assault is ruining our schools, families, military, and sports. New York: Sentinel HC 2005.

[26] U.S. Bureau of Labor Statistics. Highlights of women's earnings in 2005. (Publication No. 995). Washington, DC: U.S. Department of Labor, 2006 September. Retrieved 2008 August from: http://www.bls.gov/cps/cpswom2005.pdf.

[27] Curphey S. (2003, May 9). Safety net is weaker for unemployed women. Women's e News 2003, May 9. Retrieved 2008 September from: http://www.womensenews.org/article.cfm/dyn/aid/1316.

[28] Ehrenreich B. Nickel and dimed: On not getting by in America. New York: Metropolitan Books 2001

[29] Kijakazi K, Primus W. Options for reducing poverty among elderly women by improving SSI. Center on budget and policy priorities, 2000. Retrieved 2008 September from: http://www.cbpp.org/3-1000socsec.htm.

[30] Faludi S. Backlash: The undeclared war against American women. New York: Doubleday 1991.

[31] van Wormer K, Davis DR. Addiction treatment: A strengths perspective. Belmont, CA: Cengage 2008.

[32] Faludi S. Stiffed: The betrayal against the American man. New York: William Morrow \& Co. 1999.

[33] Chesney-Lind M, Pollock J. Women's prisons: Equality with a vengeance. In: Merlo A, Pollock J, Eds. Women, law and social control, Boston: Allyn and Bacon 1994; pp. 155-77.

[34] Dutton DG, Nicholls T, Spidel A. Female perpetrators of intimate violence. In: Buttell F, Carney M, Eds. Special Issue, J Off Rehab 2005; 41 (4): 1-32.

[35] Rennison CC. Intimate partner violence 1993-2001. Bureau of Justice Statistics (BJS Publication No. 197838). Washington, DC: U.S. Department of Justice, 2003.

[36] Dominelli L. Anti-oppressive social work theory and practice. Hampshire, UK: Palgrave MacMillan 2002.

[37] Farr K. Sex trafficking: The global market in women and children. New York: Worth 2005.

[38] Anderson R. Home front casualties. Seattle Weekly 2005 September. Retrieved June 2006 from: www.seattleweekly.com.

[39] Corbett S. The women's war. New York Times Magazine 2007, March 18. Retrieved 2007 June from: http://www.nytimes.com/ 2007/03/18magizine/18cover.

(C) Katherine Stuart van Wormer; Licensee Bentham Open.

This is an open access article licensed under the terms of the Creative Commons Attribution Non-Commercial License (http://creativecommons.org/licenses/by$\mathrm{nc} / 3.0 /)$, which permits unrestricted, non-commercial use, distribution and reproduction in any medium, provided the work is properly cited 